Отримано: 5 березня 2019 р.

Прорецензовано: 11 березня 2019 р.

Прийнято до друку: 18 березня 2019 p.

e-mail: visych@oa.edu.ua

DOI: $10.25264 / 2519-2558-2019-5(73)-317-321$
Вісич О. А. Жанрово-стильова диспозиція метадрами. Наукові записки Національного університету "Острозька академія»: серія «Філологія». Острог: Вид-во НаУОА, 2019. Вип. 5(73), березень. С. 317-321.

УДК 82.02/.09

Вісич Олександра Андріївна,

кандидат філологічних наук, доцент кафедри украӥнської мови і літератури

Національного університету «Острозька академія»

\title{
ЖАНРОВО-СТИЛЬОВА ДИСПОЗИЦІЯ МЕТАДРАМИ
}

У статті здійснено співставлення генези метадраматичної поетики із загальної еволюиією драматичного жанру в історикокультурному аспекті. Метадрама з характерними для неї авторефлексивністю в тій чи іншій мірі була затребувана у всі епохи. Простежено загальну хронологію поповнення мистецького інструментарію метадрами. Доведено, щзо, пропри безперервність метадраматичної традииї, ї̈ форма зазнала суттєвої концептуалізації у ХХ ст. і стала тотальною ознакою драматургї постмодерну.

Ключові слова: метадрама, жанр, античність, бароко, класицизм, романтизм, модернізм.

\author{
Oleksandra Visych, \\ PhD of Philological Sciences, Associate Professor, National University of Ostroh Academy
}

\section{GENRE AND STYLE DISPOSITION OF METADRAMA}

The article deals with the genesis of metadramatic poetics due to the evolution of the dramatic genre in the historical and cultural aspects. It is traced the general chronology of replenishment of metadramatic techniques. It is proved that, despite the continuity of the metadramatic tradition, its form has undergone a significant conceptualization in the twentieth century and became a total sign of postmodern drama.

Metadrama represents the self-reflexive intentions of a play, its, intertextual and cross-cultural potential. The theatre as a part of a drama poetics confirms the conventionality of the world.

Antique metadrama was realized due to drama's close connection with myths and rituals, and involved a part of the audience into the stage action. In Renaissance, the play-within-the-play became the basis of metadramatic poetics. Syncretism of baroque drama was largely based on metadramatic essentially interlaced interludes. The aesthetics of classicism limited forms of metadrama, but at the same time gave an opportunity for the development of its invariants in parody genres, as well as in rehearsals. Motifes of dream, illusion, mystery became important for of romantic metadrama. Despite the natural conflict of metadramatic form with the aesthetics of realism, this epoch influenced the formation of anti-theatrical rhetoric within dramatic texts, which became the basis of the metacritical discourse of drama in twentieth century. Conceptualization of metadrama at various levels increased in literature of modernism with its inherent gaming nature. In general, writers of the twentieth century creatively used the full potential of metadrama experience of the past. The total use of metadramatic forms and techniques by avant-garde writers and postmodernists predetermines the deepening of researching of metadrama and comprehending its numerous models.

Key words: metadrama, genre, antiquity, baroque, classicism, romanticism, modernism.

Постановка проблеми. У руслі досліджень металітератури актуальним видається на сьогодні осмислення категорії метадрами, зокрема, з огляду на послідовну інтенсифікацію їі форм у світовій драматургії. Феномен метадрами доречно розглядати у щонайменше двох ракурсах: як приклад метаізації тексту, і в цьому сенсі вона потрапляє в ряд металітератури, метапрози тощо; і як жанрове утворення, яке потрапляє в ряд понять, як-от: трагедія, комедія, водевіль тощо. Зауважмо, що метадрама претендує на заміщення усталених жанрів: коли на перший план виходить «олітературнення» тексту, театральна варіативність фрагментів, занурення в народження театрального артефакту з наявністю режисера, акторів тощо, то традиційний жанр втрачає всі свої характерні риси, натомість його прикмети стають полем гри для метадраматичних експериментів.

Аналіз останніх досліджень і публікацій. Появі терміну «метадрама» сучасна гуманістика завдячує Л. Абелю та його праці «Метатеатр: новий погляд на драматичну форму» (1963). Подальший розвиток концепції реалізовується у роботах Р. Хорнбі, К. Фівег-Маркс, С. Свйонтки, Х. Рути-Рутковської, М. Джодар Пейнадо, А. Макарова та ін. Серед пріоритетних напрямків метадраматичних студій можна виокремити питання типології, особливостей функціювання поетики метадрами у координатах національних літератур. Утім не менш важливим для розкриття природи метадраматичної форми вважаємо визначення жанрово-стильового співвідношення метадрами з історичними жанровими канонами.

Метою статті $є$ окреслення концептуальної та структурної диспозиції метадраматичної форми стосовно домінантних напрямів світової драматургії в історико-культурному аспекті.

Виклад основного матеріалу. Метадрама вповні проявилась вже в античній літературі, на що вказують ряд дослідників (Т. Постлевейт, Т.-С. Девіс, Н. Боро), що зафіксували початки метадраматичної поетики в творах Арістофана, Плавта, Софокла. Самоусвідомлення (метафікція) в грецькій драмі постає з динаміки розігрування святкового агону в контексті демократичних полісів і стає очевидною в Есхілових трагедіях задовго до творчості Еврипіда, до народження Арістофана [7, с. 5]. Сценічна умовність будувалась із врахуванням обізнаності демосу з ритуалами, що розігруються перед ним та 3 перспективою залучення глядачів до театрального дійства (передусім до сцен суду, якими часто завершувались вистави). Актори нерідко вступали в діалоги з публікою, а сама публіка теж переживала роздвоєння на частину, задіяну безпосередньо в дійстві, і ту, що залишалась у статусі спостерігача. 
Ключем метадраматизму античної драми є також образ Гермеса: під час постановок він наважувався говорити від імені автора до аудиторії, з'являвся у численних метадраматичних вставках. Актуалізації віртуального світу в драматургії сприяв популярний мотив божевілля, який слугував розкриттю художнього потенціалу роздвоєння особистості й отримав подальший розвиток у мотиві двійництва в драматургії. Дуже часто драматична ілюзія в античному театрі переривалась, але це було зумовлено наперед тим, що театр Давньої Греції суттєво відрізнявся від театру пізніших епох, зокрема тим, що, за висловом Г. Доброва, грецькі трагедії і комедії грались не просто перед глядачем, а для глядача [7, с. 12]. Металітературність античної драми доводить врешті-решт незаперечний факт того, що вся вона побудована на міфах, тобто призначення театру полягало в тому, щоб дати друге життя вже наявному артефактові. Епізація драми, використання прийому Mise en abyme, комічний контрафакт - всі ці аспекти сповна характеризують давньогрецьку драматургію.

Етапом формування метадрами стала доба ренесансу, коли чітко виокремився прийом «п'єса в п’єсі». 3 його допомогою в доробку Мерло, Шекспіра, Калдерона п’єса коментує саму себе або театр загалом, виводячи реципієнта на рефлексію роботи театрального артиста як особливої інстанції. На межі ренесансу і бароко зафіксовано появу персонажа-актора у драматичних творах, і ця особливість персоносфери ускладнила сприйняття сценічної правди. Отож актор на сцені разом з ситуативним глядачем створюють модель театру-дзеркала. Ця метадраматична ознака буде знову яскраво актуалізована в театрі XX ст., $з$ його тяжінням до абсурдистських мотивів. Можна уточнити, що якщо у XVI ст. актор появився як персонаж (герой), то у метадрамі героя репрезентовано як актора.

Українська література бароко дає право говорити про витоки національної моделі метадрами. Метадраматичність переконливо засвідчує українська шкільна драма (XVII - XVIII ст.), художня система якої дозволяла поєднувати образи історичних постатей, алегоричних чеснот, абстрактних понять тощо. Поява метадраматичних елементів сприяла синкретизму високого і низького стилю. Композиційно це проявилось у вставках до текстів з біблійним сюжетом інтермедій сатиричного характеру зі сценами з побуту простого народу. Разом з тим широко застосовувались метадраматичні елементи та прийоми грецького і римського періоду: хор, епілог, епізація. Метадраматичний потенціал барокових форм, таких як містерія, мораліте, агіографія, міракль, через кілька століть почали використовувати у драматургії модернізму. У першій половині ХХ ст. тенденції відродження алегоричного (барокового) театру можна знайти в творах Лесі Українки, І. Костецького, Ю. Косача та ін. українських драматургів.

Поруч з химерним бароко в Європі епохи утвердження абсолютистських держав стала поширюватися естетика класицизму, яку характеризували тяжіння до універсальності, раціоналізму, чіткості месиджів і стрункості композиції. Однак така зорієнтованість на прагматизм не завадила розвитку метадраматичної поетики, яка здебільшого була презентована пародійними жанрами. Ця епоха відзначається розквітом метакритичного дискурсу, а серед тогочасних жанрів великий успіх випав на долю п'єс-репетицій, які зумовили утвердження саморефлексійності у драматичних текстах і вимагали нового глядача - освіченого, з неабияким театральним досвідом, здатним прочитати масу театральних алюзій у таких виставах.

Однією з найбільш відомих п’єс-репетицій вважають комедію Ж.-Б. Мольєра «Версальський експромт» (1663). Це своєрідна імпровізація на тему процесу театральної творчості, що створена як авторська реакція на дискусію навколо його ж таки п’єси «Школа дружин» (1662). В Англії родоначальником цього жанрового формату став Дж. В. Бекінгем, який очолив групу авторів для створення комедії «Репетиція» (1671), що була пародією на надмірне захоплення ефектами та екзотикою драматурга Дж. Драйдена в так званих «героїчних п’єсах». У цьому жанрі активно працювали Г. Філдінг: його «Пасквін, драматична сатира на сучасність» (1736) складається 3 двох репетицій - комедії «Вибори» та трагедії «Життя $i$ смерть здорового глузду»; Р. Брінслі Шерідан з п’єсою «Критик або репетииія однієї трагедії» (1779) та ін. Переважно пародійні спектаклі-репетиції ставали своєрідними кафедрами для політичної сатири, отож театр, вдаючись до метадраматичних прийомів, по суті брав на себе функції архетипного блазня. Як правило, автор п’єси-репетиції не тільки «роздумує над викликами часу художника, винахідливо доповнює метафорику зіставлення світу - театральної сцени - політики - історії та iii гравців, але і прагне за допомогою драматичних характерів показати труднощі, радощі, втрати і набуття письменницького ремесла» [1, с. 24]. Навіть відомий теоретик драми Корнель 3 його пристрастю до нормативної поетики у власній драматичній творчості засвідчив нездатність опиратися потужній естетиці подвійного мімезису. Попри його намагання повсякчас розвінчати ілюзію, він неодноразово вдавався до ії візуалізації, використовував покликання і самопокликання, що врешті дозволило сучасним дослідникам вивчати творчість драматурга у вимірах метадраматизму.

Доба утвердження романтизму створювала сприятливі умови для розвитку метадрами, якщо взяти до уваги іiї плекання поривів від реального до ірреального, ідеалізацію фікційного світу. Новий герой на сцені вже не покладався на міметичні декорації, а глядач мусив піднімати регістр своєї уяви, щоб стати співтворцем ідеального світу. Проте мусимо визнати, що нові обставини водночас гальмували театральні шукання, що в результаті призвело до певного відмежування драматургії від театру, котрий не міг відтворити за допомогою традиційного реквізиту світ бажаний, омріяний, нетутешній. Тим не менше метадрама поповнила свій художній арсенал завдяки нарощенню та урізноманітненю мотивів сну, марень, ілюзій, потойбіччя. Свій внесок в метадраматичні надбання літератури зробили Р. Бернслі Шерідан (п’єса «Критик»), Дж. Колман («Жінка драматург»), Дж. Пауел («Приватні вистави») та ін.

Прикладом метадраматичного мислення слід вважати і знамениту трагедію В.-Й. Гете «Фауст», жанр якої ще трактують і як філософська драма. Сюжетом для цього твору послужили матеріали, розміщені в книзі «Історія доктора Фауста» (1857), що вмістила деякі легенди і притчі. Метадраматичний характер твору Гете підтверджує і той факт, що драматична фаустіана була розпочата значно раніше. Нагадаймо, що «Трагічну історію доктора Фауста» (1588) написав англійський драматург Крістофер Марло, над цією темою працював Г. Лессінг та інші автори, лубкові варіанти Фауста розповсюджувались в репертуарах ярмаркових балаганів, лялькових постановок.

Упродовж тривалого написання «Фауста» (1770-1831) світогляд та естетичні орієнтири Гете зазнали еволюції, але 3 висоти часу в цьому тексті очевидні численні філософські ідеї та образи, які вважають романтичними символами. Варто звернути увагу, що на початку твору подається «Театральний вступ», який є зразком рефлексії сценічного мистецтва. Директор театру в товаристві з Поетом та коміком міркує про призначення театральної установи, очікування глядачів, ймовірність створити ідеальну виставу, а не лише масове видовище, яке приносить дешевий успіх: 
Скажіть, яким повинен бути

Театр у нашій стороні?

Бажаю я завжди юрбі годити:

Вона живе, дає й другому жить.

Стовпи стоять, поміст із дощок збитий,

І всяк туди, на свято мов, спішить.

Сидять усі вже, звівши вгору брови,

До подиву і захвату готові.

Я знаю, як сподобатися всім,

А все ж чомусь сьогодні страшнувато;

Хоч путнє щось незвично бачить їм,

Але вони читали страх багато.

Як змайструвать виставу нам таку -

Нову, й живу, і людям до смаку? [2]

У пролозі приділена також увага власне критеріям ідеальної п’єси, до яких зараховують збалансованість фантазії, волі, пристрасті, розуму і дурості. На думку Коміка, текст повинен відповідати запитам публіки, бути насиченим напруженими перипетіями, тоді як його опонентом виступає Поет, що вважає за недоцільне торгувати високим словом перед злиденним натовпом.

Безсумнівно, Гете розпочинає свого «Фауста» метадаматичним прологом не так задля фіксації завжди злободенної і нерозв'язаної проблеми, що гостро стоїть перед драматургом, актором і керівником театру, як заради моделювання грандіозної ідеї перетворення світу в межах театрального простору, осмислення вічних фаустівських питань. Відтак саме в цій частині Гете проголошує свій масштабний задум: відобразити на кону всесвіт, пройти «із неба через землю в пекло» [2]. Отже «Пролог у театрі» - це дзеркало, свідоме подвоєння у координатах театрального ембріону тих різнобічних інтенцій, які живитимуть філософські ідеї всього твору.

Звернення Гете до відомої теми Фауста багато в чому набувало оригінального звучання завдяки використанню романтичної іронії. Цей засіб був цілком доцільним саме в метадраматичній формі, яка дає можливість досягати персонажам певного дистанціювання від своїх ролей, підстави вплітати в сатиричний струмінь тексту функції самокритичності. Самоіронія досягалась навіть шляхом театрального самоспоглядання та коментування власних поз та гримас персонажами. Акцентуючи на металітературності «Фауста» Гете, дослідник романтизму Ф. Барвік, слушно стверджує, що саморефлексивні прийоми письменника забезпечують подвоєння романтичної іронії, віддзеркалення авторського самопізнання, а також дозволяють висміювати непристойні моди і смаки, дотепно порушувати канони репрезентації [6, с. 170].

У свою чергу естетика реалізму відіграла важливу роль у формуванні опозиції умовності, ілюзійності, яка $є$ основою метадраматичності, і пізніше конфлікт реального та ірреального став одним із найважливіших компонентів проблематики метадраматичних досліджень. На думку багатьох дослідників, для прихильників реалізму метадраматична поетика була неприйнятною, втім, у драмах кінця XIX ст. стали дуже впливовими дві метадраматичні тенденції, які адаптувались у реалістичній парадигмі: антитеатральність та метакритика. Сам образ театру в реалістичних п'єсах послідовно формується як територія аморальності. Актор - це радше соціальний тип, а не митець, вартий зневаги з боку філістерів, які не вважають «кривляння» гідною професією. Однак помітною $є$ і поступова реабілітація героя-актора, принаймні у вузькому театральному колі талант визнається унікальною цінністю. Подекуди знаходимо й ідеалізацію служителя сцени, з його піднесеними прагненнями і випробуваннями, які випадають на долю через обструкцію вульгарного оточення.

Схильність до метакритики проявляється в конкретизації діалогів, наведення вражень про певні вистави, що мали на той час резонанс, оперування такими поняттями, як «школа», «метод», амплуа», у раціоналізації театрального дискурсу, виявленні полемічних поглядів тощо. Поступово ці маргінальні явища починають наближатися до провідних концентрів, і врешті-решт тема театру стає рівноправною з іншими темами, популярними для реалістичного періоду драматургії. Небезпідставно можна констатувати, що посилення театральних проблем, саморефлексійних інтенцій у драматичному тексті засвідчували віяння модернізму, які незабаром стали панівними і дали новий поштовх для розвитку метадрами в літературі і метатеатру на сцені.

Доба модернізму засвідчила новий виток інтересу до homo ludens, він стає провідним суб'єктом і об'єктом театральних видовищ, які почали претендувати на ігрові антропологічні дослідження. У численних модерністських п’єсах, написаних представниками різних національних культур, у центрі уваги опиняється театральна проблематика. Метадрама в модернізмі стає підкреслено ігровою формою, автори все більше абстрагувалися від дійсності, їхні п'єси все менше претендували на дзеркальне відображення реальності. Модерна метадрама скоріше займає свою нішу в концепції «мистецтво для мистецтва», водночас претендуючи на аналітизм та інтелектуалізм, який спрямовувався насамперед на літературні та театральні явища. Перефразовуючи Пікассо можна сказати, що метадрама показує світ не таким, яким вона його бачить, а яким його мислить.

Феномен метадрами XX ст. полягає в тому, що вона синхронізувалась з поступом естетико-філософської думки. Модернізм зарекомендував себе порою усвідомлення ігрової природи культури, що зумовило пік експериментів на театральних підмостках. Причому в різних модерних напрямках метадраматична форма була цілком органічною, можна говорити про своєрідне зрощення метадрами з новими мистецькими відгалуженнями, особливо наглядною є іiї затребуваність в авангардних формах модернізму.

За спостереженнми О. Соколової, на межі XIX та XX ст. розпочався етап напрочуд багатогранного проявлення концептуалізації театру в драматичних тестах, зокрема дослідниця виділяє такі аспекти:

- театр як особлива естетична реальність, що виникає в ігровому просторі;

- театр як механізм створення і програвання певної життєвої ситуації;

- театр як взаємозв'язок «актор-персонаж-глядач»; 
- роль, маска і маріонетка в їхньому прямому і символічному значенні;

- імпровізаційність як обов'язковий складник театрального спектаклю [5].

Особливу увагу модерна драма приділяє оголенню творчого процесу, йдеться про народження вистави, реалізацію театрального задуму, включно з безпосереднім створенням п’єси. Основним конфліктом у модерній метадрамі $\epsilon$ протистояння героя і умовно-театрального буття. Однак локус сценічної бутафорії, приховування істинного за маскою, залежність від сценарію тощо не звужує філософські проблеми, що порушуються в тексті, і головними серед них є проблема саморефлексії та самоідентифікації. Сам процес самопізнання відбувається власне через роль, отож бути «іншим» - це можливість знайти себе, стати «собою», хоча шлях цей, як правило, не має кінця. Метадрама зумовила двоїстість таких театральних категорій як «дійова особа», «місце дії», «слово», «час», «простір», посилила розмивання кордонів між ілюзорністю і явою, вдаючись до варіативності дії, трансформації персонажів, підміни героїв, обміну ролями, причому останні перетворились на самодостатню категорію в персносфері низки п'єс.

Метадраматургом XX століття небезпідставно називають Антона Чехова. Яскраво багатошаровість образів, театральний дискурс, виклична метакритичнісь проявились уже в першій п’єсі письменника «Чайка» (1896). У ній гостро звучить назріла необхідність оновити театральну традицію, яка перетворилась, за висловом чеховського персонажа Трепльова, на рутину. Прагнення до вираження абстрактних ідей зумовило інтенсифікацію репрезентації театру - в літературі і на сцені - з внутрішнього боку, сповненого самоідентифікаційних проблем, що потребувало витонченого глядача, естета й інтелектуала, здатного прочитувати пласти культурної пам'яті, двоплановість вигадки й вимислу, множинність варіантів рецепції зіграного, подекуди неодноразово, причому рецептивну неоднозначність нерідко провокують самі персонажі, які включаються в обговорення виконання тих чи інших ролей. Автор метадрами пропонує публіці гру як смислоутворюючий процес, завжди незавершений і невичерпний.

Метадрама доби модерну стала найпереконливішою ілюстрацією новітніх тенденцій, саме в ній практично наочно зафіксована «переорієнтація з міметичного принципу відтворення дійсності, характерного для народницького дискурсу... на моделюючий, знаковий: символічний, метафоричний, екзистенційний» [4, с. 9]. Особливо згущено метапоетика проявляється у творчості Л. Піранделло. Його театральна трилогія «Шість персонажів у пошуках автора» (1921), «Кожен на свій лад» (1924), «Сьогодні ми імпровізуємо» (1930) підняла метадраму на небачений раніше культурософський рівень. Автор пропонує художню версію таких актуальних проблем, як комунікативний зв'язок «автор-актор-персонаж-глядач», ілюзія реальності й реальність ілюзії, фіктивність кордону між мистецтвом і життям, філософія гри як філософія життя. За спостереженнями дослідниці І. Зуккер, Піранделло «робить видимим співвідношення актор - роль і надає своїм персонажам можливість тлумачити власну роль і розмірковувати з її приводу» [3, с. 10].

Попри цілковитій зосередженості на народженні театрального артефакту в п’єсі «Шість персонажів...» Піранделло разом 3 тим порушує складні богословські питання, намагається визначити природу взаємозалежності між Богом-деміургом i його творінням. 3 часом новаторство італійського лауреата Нобелівської премії отримало розповсюдження у шуканнях численних авторів, а сама метадрама стала неодмінно асоціюватися з концептуалізацією театрального дискурсу, засадничою відмовою від копіювання реальності. Натомість драматурги повсякчас актуалізують традиції прадавнього театру (антична трагедія, п'єса-репетиція, театр масок тощо), подекуди радикально переосмислюючи канон і наповнюючи старі знаки та прийоми новим змістом.

Високий модернізм продовжив експерименти ранніх модерністів. Наприклад, п’єси Т. Стоппарда засвідчують суб'єктивізацію фрагментів та осколків драматичної спадщини минулого (цитати, персонажі, ситуації) у театральній дійсності нового художнього тексту. Таким чином автор стверджує, що естетична пам'ять покоління стає призмою, крізь яку індивідуум сприймає сучасний світ. Свідомий еклектизм театральних категорій, метадраматичних стилів і прийомів, класичних і модерних ідей передбачає посилення стратегії участі глядача як співтворця театрального/читацького феномену. Інтелектуального декодування у руслі метадрами потребують твори А. Шніцлера, Ж. Жене, Ж.-П. Сартра, Ж. Ануя, які у середині XX ст. запропонували п’єси, що стали етапними в розвитку драматургії і театру та засвідчили перехід до естетики постмодернізму. Особливий внесок у цей перехід зробили представники драми абсурду, яку ми розглядаємо як течію модернізму. Творчість драматургів-абсурдистів репрезентує багатовимірний світ, у якому дезорієнтована людина намагається витворити власний метадраматичний лабіринт, гру й інтелектуальний виклик для глядача, що також мислить себе загубленим в алогічному довкіллі.

В українській літературі першої половини XX ст. також спостерігається поступовий метадраматичний зсув в художньому мисленні авторів. Модерністську реформу метадрами запропонували Леся Українка, В. Винниченко, А. Крушельницький, Я. Мамонтов, М. Куліш, Л. Коваленко, Ю. Косач, І. Костецький та ін.

Постмодерний період мову метадрами зробив загальнодоступною. Інтенсифікація прийомів метарефлексії та деконстркуція репрезентації, створення багатошарової реальності, кожна з яких відкриває власну істину, відкриття нових векторів метадраматичного аналізу - все це вказує, що постмодернізм став важливим етапом еволюції метадрами. Варто підкреслити, що постмодерний драмопис активно використовує тілесність, не цурається жорстокості. У геометричній прогресії зростає використання сучасними авторами пастишу, що дозволяє видозмінювати відомий сюжет, вводити нові персонажі, створювати гіпертекстуальні концепції та використовувати невичерпний потенціал драматургічних шедеврів минулого. Як і раніше, простежуються послідовні спроби відкрити нові грані знаменитого шекспірівського «Гамлета», що доводять постмодерністські переробки цього твору А. Застирця, Б. Акуніна, Л. Філатова, Л. Подерв’янського, Ю. Тарнавського та ін. Яскравим маркером сучасної метадрами $€$ використання різних медійних засобів, насамперед кіно, телебачення, що сприяє унаочненню химерності і роздвоєння світу (В. Діброва, О. Ірванець, П. Ар'є та ін.).

Отже постмодерна драма - це драма самопрезентації та самоусвідомлення, що спрямована на розширення драматичного світу шляхом конструювання додаткових реальних / ірреальних площин. Пріоритет гри у ній завжди передбачає наявність засадничої філософсько-естетичної парадигми, яка нагадує ребус. Інтерпретація такого тексту може висувати низку ідей та асоціацій, що прочитуються лише за умови відповідного читацького та глядацького досвіду реципієнта. 
Висновки. Метадрама є результатом еволюції драматичного жанру, засвідчує авторефлексивні інтенції п’єси, іiі інтермедіальний, інтертекстуальний і кроскультурний потенціал. Залучення до поетики твору феномену театру (у найширшому соціально-культурному сенсі: від топосу сцени до психології побутового акторства й філософського узагальнення) підтверджує умовність та апріорну постановочність світу.

Метадраматизм античної драми реалізовувався завдяки ії тісному зв'язку з міфами та ритуалами, специфічним законам постановки, що передбачала залучення частини аудиторії у сценічне дійство тощо. В епоху ренесансу чітко окреслюється прийом «п'єса в п’єсі», що став основою метадраматичної поетики. Синкретизм барокової драми значною мірою будувався на метадраматичних по суті вставних інтермедіях. Естетика класицизму значно обмежила функціювання метадрами, проте водночас дала можливість для розвитку іiї інваріантів в пародійних жанрах, а також у п'єсах-репетиціях. Важливими для поетики романтичної метадрами стали мотиви сну, марень, ілюзій, таїни мистецтва. Попри закономірний конфлікт метадраматичної форми з естетикою реалізму ця епоха вплинула на формування антитеатральної риторики в межах драматичних текстів, що стало основою метакритичного дискурсу драматургії XX ст. Концептуалізацію метадрами на різних формозмістових рівнях запропонувала епоха модернізму, з ії іманентною ігровою природою. У цілому драматурги XX ст. творчо використовували весь потенціал досвіду метаізації п’єси минулого. Тотальність використання метадраматичних форм та прийомів письменниками-авангардистами та постмодерністами зумовлює сучасне поглиблення студій метадрами та осмислення іiі чисельних національних модусів.

\section{Література:}

1. Ватченко С. Автор в театральных текстах Г. Филдинга: от амплуа к характеру. Від бароко до постмодернізму. 2014. № 18. C. $16-24$.

2. Гете В.-Й. Фауст. Переклад з нім. М. Лукаша. Режим доступу: http://www.ukrcenter.com/Література/Йоганн-Вольфганг-Гете/26242/Фауст-Пролог.

3. Зуккер І. Драматургічна концепція Луїджі Піранделло: автореф. дис. ... канд. філол. наук: 10.01.04. Київ, 1997. 24 с.

4. Свербілова Т., Малютіна Н., Скорина Л. Від модерну до авангарду: жанрово-стильова парадигма української драматургії першої третини XX століття. Черкаси, 2009. 598 с.

5. Соколова Е. Игровые концепции в драматургии эпохи модернизма. Метадрама: автореф. дис. ... канд. искусствоведения: 17.00.01. Санкт-Петербург, 2009. 22 с.

6. Burwick F. Romanticism: Keywords. Wiley-Blackwell. 400 p.

7. Dobrov G. Fegures of Play. Greek Drama and Metafictional Poetics. New York. Oxford University Press. 2001. 242 p. 